Journal of Educational Method and Technology Vol. 1 No. 2, September 2018

P-ISSN 2622-8459 E-ISSN 2622-8467

http://ejournal.unima.ac.id/index.php/jemtec

\title{
English Training For Sunday School Of Gmim Tabur Kasih Malalayang Manado
}

\author{
N F R Samola ${ }^{1}$ \\ ${ }^{1}$ Universitas Negeri Manado, Indonesia \\ corresponding author: ${ }^{1}$ nurminsamola@unima.ac.id
}

\begin{abstract}
Facing era of globalization needs people to prepare human resources mainly in the sector of science and technology. To have a good mastery of technology someone requires sufficient knowledge in facing global world needs which is known as a competitive era. In this case,the role of English or other foreign languages is very important in mastering communication technology or even for direct communication using English. English is not only fulfilling academic purposes since the mastery is only focused on the knowledge of the language itself, however it is used as a tool of global communication. This supports the Indonesian government program of Visit Indonesia and Pesona Indonesia for the purpose of developing the prosperity of Indonesian society. As cityzens of Manado, the capital city of North Sulawesi, is supporting the program by giving special attention to the early age of school; Sunday School Children of Tabur Kasih Malalayang teaching them simple and practical English sentences and vocabularies. English Nursary Rhymes including songs were chosen as teaching media. This training was aimed at giving the children simple English sentenses and vocabularies. The training was done in Manado Tabur Kasih Congregation attended by 30 children.
\end{abstract}

Keywords: English training, Sunday School Children

\section{Introduction}

Manado City is located at the tip of northern peninsula of Sulawesi island, geographically $124^{\circ} 40^{\prime}-124^{\circ} 50^{\prime}$ BT and $1^{\circ} 30^{\prime}-1^{\circ} 40^{\prime}$ LU. This city has tropical with average temperature $24^{\circ}-27^{\circ} \mathrm{C}$. the average rainfall is $3.187 \mathrm{~mm} /$ year with the driest climate on around August and the wettest on January. The average intensity of solar radiation is $53 \%$ and relative humidity $\pm 84 \%$. The width of its 
land is 15.726 hectare. Manado is also the city with 18,7 kilometers long of its coastline. The altitude interval is between $0-40 \%$ with the highest is Mount Tumpa.

The waters area of Manado covers Bunaken island, Siladen island, and Manado Tua island. Bunaken and Siladen island have wavy topography with the highest top as 200 meters. While Manado Tua island is the highest mountain with its \pm 750 meter. Meanwhile, waters of Manado bay have 2-5 meters deep on the boundary line where the coastlines of continental slope meet. This depth becomes a barricade for until now the intensity of damage Bunaken National Park is relatively low. Manado City is contiguous with Minahasa Regency and Mantehage narrows from the North, with Minahasa Regency from the East, with Minahasa Regency from the South and Manado Bay from the West. The distance from Manado to Tondano is 28 kilometers, 45 kilometers to Bitung and 58 kilometers to Amurang. Manado City consists of nine subdistricts namely: Bunaken, Malalayang, Mapanget, Sario, Singkil, Tikala, Tuminting, Wanea and Wenang.

Facing era of globalization needs people to prepare human resources mainly in the sector of science and technology. To have a good mastery of technology someone requires sufficient knowledge in facing global world needs which was known as a competitive era. In this case, the role of English or other foreign languages was very important in mastering communication technology or even for direct communication by English. As a tool of global communication, English must be actively mastered either in oral or written form. It ws not possible that the rapid development of technology requires us to be more proactive in responding global information current in meeting market needs. As a lingua franca, English was not only fulfilling academic purposes since the mastery was only focused on the knowledge of the language itself, however it was used as a tool of global communication. To be good in English mastery, the process of learning must have more focus on practicing (Trial and Error) so that the learning will actively contribute in raising opinion/idea that was in line with the reality.

As citizens, we had a crucial role in raising up National Foreign Exchange through tourism sector. The preparation of a practical language communication that could be directly applied in daily conversation was necessary. For instance, practical English learning. The effort of English learning in terms of good and correct daily conversation Sunday School Children of Tabur Kasih Malalayang, had not been optimally undertaken and its role had not yet run as it should. This might be caused by the less of knowledge about basic English.

Sunday School Children of Tabur Kasih Malalayang was categorized as those who were still under five years old and those who were already in Kindergarten and Elementary school. The training target was children in their early age of school. The students of Elementary School were basically 
enthusiastic to poem and songs as Kindergarten students. Although it could not be denied that elementary students were more interested to modern pop songs which actually more relevant to teenagers and adults rather than songs that were relevant to their age. Many researches had been undergone to determine the effectiveness of poem and songs for children in developing students' ability. Studies had shown that songs for children would be able to help kids that find difficulty in learning to read and recognize words.

Singing activity presented possibility for kid to develop listening skill and memory for they work hard to memorize words of the lyric. Therefore, the teaching of children songs was able to help children in figuring out the way of speaking. It had been confirmed by several researchers that gold age of learning was six to nine years old. Therefore, Nursery Rhymes training or lyric of English songs for children was considered effective as a tool of learning English for Elementary students. The use of learning method through Nursery Rhymes was expected to be able to assist students in learning English in easier and please way. Students were also expected to study to enrich their knowledge about English vocabulary mastery so that students' interest in learning English through songs would raise. This activity was also expected to result students with sufficient interest and ability at elementary level so that it would be easier for them to comprehend English vocabularies once they study in higher level. As we know that English was a required subject at any school.

The use of song as tool of learning was relevantly related to hearing instrument. Physiologically, hearing is a wave of sound that enters through the outer side of ear, to eardrum, and converted into neural stimulation and delivered to brain. Song is one of tools that can assist the process of delivering either in form of verbal auditive or non-verbal or its combination. Song can be utilized as an assistive tool to different fields of scientific disciplinary and be used to reach what is desired, for the song is so effective to catch students' attention in learning process. Song is also can be used as a learning tool of foreign language, especially English, the use of song can produce particular interest to students, for the student can enjoy song and music while learning English.

Song selection must be done accurately because it was not possible to learn English by using an up-beat or quick tempo song and unwell-structured words. Teacher had to pick appropriate song for the song selection was really important in learning process.

The target of this training is to a) to know and to be able to perform English in practical way of the Sunday School Children; b) to increase English vocabulary of the Sunday School Children; and to increase the interest and motivation in learning practical English for the Sunday School Children

The outcomes that are brought about from increasing English skill of Sunday School Children of Tabur Kasih Malalayang: a) the increase of 
knowledge and comprehensiaon of English and b) the increase of skill and comprehension on foreign cultural aspect to Sunday School Children.

\section{Theoretical Base}

Learning foreign language including English is a developing skill and desired to be requirement for individual or institution. According to Chomsky, human nature is able to learn mother tongue automatically because the system that was already established since his birth. As believed by Chomsky, Fromkin and Rodman explained that the phenomenon of the fastest and the most accurate way of language mastery occurred around 0 to 3 years old, from that age, language mastery will be facing difficulty for human brain has already been divided into some division for particular task. While at the age of 0 to 3 years old, specific divisions are not found yet in human brain. From the conclusion of linguist and neurologist above, it can be seen that English mastery for student of university with mother tongue which is Indonesian language is great challenge to human brain.

The genuineness of learning English is learning its culture as well, as said by Ronald Wardaugh in An Introduction to Sociolinguistics. English is language filled with change and exception caused by its cultural change. Language elements and style are enriched by development as well as English use itself. This is the peculiarity that must be understood by those who have willing in learning English. English is one of the most learned foreign languages in Indonesia. Foreign language itself is a language that is learned in an environment where other language is mostly used in daily activities. Unlike learning the second language which is learning language in an environment where the language itself becomes the most used language for daily activities and plenty of resources are available to be accessed. For instance, learning France in particular part in Canada will be said as second language while here in Indonesia, learning France will be considered as foreign language. In this study, terminology that is going to be used to address foreign language is L2.

In the process of learning foreign language, there are factors that determine how well someone master a language that is learned by him. According to Young (1991) there six factors that contribute in determining the process of English learning in a classroom. These factors are also the level of anxiety felt by someone who is learning English. These factors are personal and interpersonal anxieties. Learner belief about language learning, instructor belief about language learning, instructor-learner interaction, classroom, dan procedures language testing. Personal and interpersonal anxieties. Personal and interpersonal anxieties cover the competitive sense to other people, the way of communication, ability to record, shyness, afraid of being in front of public, afraid of failure, how someone appreciates his or her English ability, and social anxiety. 
Personal and interpersonal anxiety determine how someone values himself in earing English as well as his relationship with others.

Looking at the level of teenager development, it can be seen that adolescence is a period of transition from child to adult. Now, changes take place on cognition, emotion and social interaction. This might have impact to the process of learning they are facing.

The second factor is his perspective towards the English learning process itself. This covers how he sees the importance of learning English and how he prioritizes, how he sees his mistakes in his perspective, as well as how he sees instructional activities that he does.

The third factor is the instructor's belief about language learning. In this case instructor is the teacher that is in charge of teaching. How teacher sees the learning process and the way he teaches contributes great influence toward the teaching and learning process. It this case, teacher perspective toward his students covers his role as a teacher and the relationship between teacher and students. If teacher has a good relationship with students, then the process of teaching and learning shall be running well and resulting better result.

The fourth sector is the interaction takes place between teacher and students. On this factor, the target is how the way teacher corrects the mistake made by students contributes anxiety to the students.

The procedure of foreign language test implementation is also a factor where anxiety appears. The procedure of language test implementation covers the format of implementation, items in test, conformity between what is learned and trained and what is going to be examined.

Language anxiety is a feeling of worry that emerges when someone learns English. According to Arnold and Brown (1999), anxiety is the main factor that usually obstructs the process of learning. The anxiety itself is a subjective feeling towards tension, state of apprehension, nervousness, and worry that are associated to the stimulation of autonomous neural system that caused by the unclear fear that indirectly relates to the object. (Spielberg, 1983).

Anxiety is divided in to three perspective namely trait, state and situation specific anxiety (anxiety that is caused by varied types of situation (Spielberg, 1983). Trait anxiety is a more permanent manner, it is able to disrupt cognitive function, and disrupt memory (McIntyre dan Gardner, 1991). State anxiety is a feeling of fear or worry to the emerge of unpleasant happening in particular time. State anxiety is the combination of trait anxiety and situation specific anxiety (Spielberg, 1983) while situation specific anxiety is an alternative concept toward state anxiety. According to Philip C. Kendall and Julian D. Norton Ford in Clinical Phsycology and Professional Dimension, the researches that use inventory to examine anxiety as an important information. Therefore, the situation has to be attached in the making of inventory itself. According to Howirtz et al 
(1986), Foreign Language Anxiety, is a worry or negative emotional reaction that emerges when learning or using English. The definition from Foreign Language Anxiety is "distinct complex of self-perceptions, beliefs, feelings, and behaviors related to classroom language learning arising from the uniqueness of the language learning process". Foreign Language Anxiety consists of 3 dimensions namely communication apprehension, test anxiety and fear of the negative evaluation.

Anxiety has minor role to the new language learner. Nowadays, the process of learning is more encouraged by motivation and language aptitude has major role in learning process. Yet, as more negative experienced found, more of anxiety will emerge. (MacIntyre and Gardern (1991). For the learning environment in classroom is able to create or present higher level of anxiety (Horwitz et al., 1986) so improving class environment to be less of anxiety needs to be prioritized by teacher. This can be undertaken by teaching the appropriate learning strategy so that students of university may be able to control the anxiety and to improve learning performance (Oxford dan Cookall, 1989).

Observing about how anxiety influences successful learning, a way of overcoming anxiety is necessarily needed. Therefore, it is important for someone who learns English to know his best way of learning English. This way of learning is called language strategies. There are some definitions of English learning. Wenden and Rubini (1987:19) define learning strategy steps, plan, and routine that are used by someone who learns so that will be able to facilitate the process of receiving, storing, retrieval and re-use of an information. According to Fearch Claus and Casper (1983:67) concern that learning strategy is an attempt to develop linguistic and sociolinguistic ability on a certain language. The process of learning strategy use is fully-realized process. Classroom where problems are solved, where inputs and assignments that are new and complicated be presented, so that someone needs an appropriate and practical way to finish the task.

According to Oxford dan Scarcella (1992:63) learning strategy is a particular action, attitude, steps that are used by student of university to improve learning process itself. A chosen learning strategy shall be able to assist in language learning, storing, retrieval, and the use of information. The strategy will be assisting student in university in learning so that English learning can be more practical, faster, more fun, more effective and can be applied in new situations (Oxford, 1990).

There are six categories of learning strategy highlighted by Oxford. These six strategies are cognitive strategies, memory strategies, compensatory strategies, metacognitive strategies, affective strategies, dan social strategies. These six strategies can be applied according to demands as it maximizes someone's possibility of success. To be considered as a learning strategy, he has to apply the strategy followed by well-comprehension about it. 
Technique of learning English as a foreign language especially for Indonesian needs appropriate technique of teaching and learning. Its position as a foreign language results English teaching class is challenge to teacher and students. Both sides put an effort to figure out the best way to express, to comprehend and to train English ability. Diane Larsen in Technique and Principles in Language Learning introduces 12 techniques of teaching foreign language. Those techniques are developed by its founder to assist students in university who learn foreign language in appropriate way which is also in line with its background. Therefore, foreign language learning and teaching technique needs to have deeper understanding about human character in the first place so that appropriate technique can be found.

Learning and teaching technique supports students' success in learning foreign language. Learning technique needs learning program to have plan on what are the things that possible to happen later during the process and when it may be used. Therefore, curriculum of teaching program will assist teacher and students to know what to discuss, how to learn, when it will end and the prediction. Douglas Brown in Principle of Language learning states the needs of knowledge and the making of learning plan. Learning plan, will accommodate the desire of students so that they can gradually speak. Steps in learning itself is arranged in curriculum program to students and teacher so that they can synergize one another in learning and teaching activity.

Music will produce note that is audible. Besides, songs and music have strong and direct connection to human hearing instrument. Through ear man will be able to learn a language by listening to its pronunciation. The language teachers use cassette as one of medias that can be used to teach a language. Cassettes used by teacher contain songs or soundtrack, especially to foreign language learning, as well as English.

Songs or audio media is a supporting media in learning English and song as auditive supporting media two functions. Werner Beile in Bausch et al (1985:263) states the two function of the media as follow:

1. Media documentation function that can store (record) authentic language (written or oral). Authentic language is the language that is used by the native without intention to teach foreign language, for instance: types of radio broadcast, songs, phone conversation, books and magazines.

2. Deductive function is a media is meant to store materials that similar to the original one. The purpose of these materials is to improve the ability of gathering the information by listening. The difference between deductive function and documentation function is the structure and the substance, if deductive function has not yet been processed or plain while documentation function has already been processed, become easier or arranged in structural boundary and lexical border according to language learning. 
From is broken down above, can be conclude that the teaching is related to two types of text, namely the real authentic text and text that is similar to the real one or text that is taken from authentic text but has been adapted for the sake of learning the art of listening.

Subyakto Nababan as quoted by Dewanti (2005: 16) highlights some uses of assistive tool as radio, recorder tape, songs, language laboratory and film for language learning as follows:

1. Give opportunity to learner to have individual training in or outside of classroom.

2. Help out/assist/equip teacher's role.

3. Listen to the native speaker in classroom so that the learning can be able to distinguish the voice out of woman, man, kid, youth, and any other register.

In other word, Subyakto puts forward that the effective use of media results important contribution in foreign language learning. Other than that, music can affect students' attitude in the process of learning foreign language. On www.sinarharapan.com edition July $9^{\text {th }} 2004$, it is said that learning language through listening to the music will make them please and they will not get bored in learning it.

The use of song in general learning environment is able to give them image of the expression found in the song for they are not only listening but sing the song along. Jamalus (1988:2) highlights same opinion that total comprehension of a song through listening activity, singing, playing musical instrument, moving as music plays, so that students have complete picture about the expression of the song.

A tension in classroom may cause students to have bad learning experience, in contrast, if the classroom environment is without tension, it means that students are having please experience. About the use of song students do not only learn to listening carefully but dig more about the structure, vocabulary and cultural aspect. It can be concluded that the use of song or music is able to introduce language and a contrast distinguish between one culture and others as it shows difference between the ability of learning carefully and comprehending vocabulary structure of foreign language. Learning a language by using song as medium is a way of learning and learning through the introductory of songs that contain the element of freedom, beside containing the comprehension of language element and literary activity, as well as the implementation in communicating.

In the process of learning in classroom, there is still one aspect that is forgotten by teacher and that is class atmosphere. Class atmosphere is one of the supporting factors in the process of teaching and learning in classroom. A tensed atmosphere will result students lose their attention in learning a language and other subjects. The other thing that needs to be concerned in learning language by using songs is the selection of slow-tempo song so that students will not be 
confused and their concentration will not be distracted and the message of the song has to be relevant to language structure that is going to be learned.

\section{Implementation Methods}

Learning foreign language including English is an improving ability and desired or required by a person or institution. According to Chomsky, the essence of human that was able to automatically learn the mother tongue was because the accessibility of language system since he was born. While the foreign language which was going to be learned is difficult. As believed by Chomsky, Fromkin and Rodman explained that the phenomenon of the fastest and most accurate way in mastering a language occurred between o to 3 years old, from that age, language mastery would be facing difficulty for human brain had already been divided into some division for particular task. While at the age of 0 to 3 years old, specific divisions were not formed yet in human brain. From the conclusion of linguist and neurologist above, it could be seen that English mastery for student of university with mother tongue which was Indonesian language was great challenge to human brain.

English is one of the most learned foreign languages in Indonesia. Foreign language itself was a language that is learned in an environment where other language is mostly used in daily activities and there is restrictiveness in learning it.

To address the problem above, method that is done is preaching method by undertaking direct training to Sunday School Children of Tabur Kasih Malalayang which close to preaching, question and answer, and practice. This problem solving is undertaken to change the atmosphere (desa sain) in which Sunday School Children of Tabur Kasih Malalayang are still not be able to communicate English in practical way. This condition will be brought to the expected condition (das solen) in which the Sunday School Children of Tabur Kasih Malalayang are able to master practical English so that communication can be built well and the increase of English comprehension.

\section{Discussion}

The implementation of this training was aimed to improve English ability of Sunday School Children of Tabur Kasih Malalayang. Other than that, this training was expected to equip participant with cultural theory which possible to contribute great impact to manner in using English.

For three days (25-27), the participants were trained by varied ways and methods so that they could comprehend English although it was simple. Varied of activities to develop and keep the participant active were conducted so that the activities could not be boring but interesting. The whole picture of the activities can be seen at the table: 


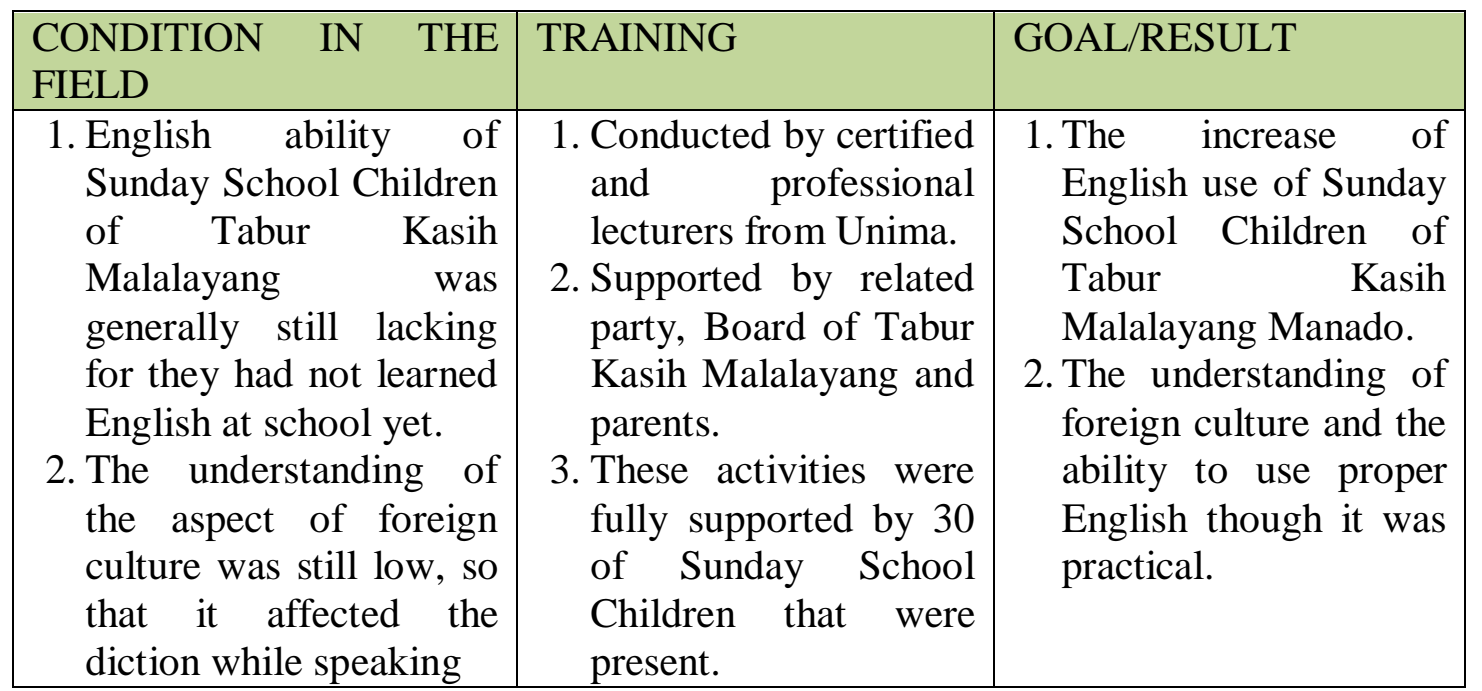

Therefore, it could be concluded that this activity was helpful to Sunday

School Children and the summary of the result of the activity are listed below:

1. Positive response from the participants.

2. Participants followed and interpreted well the whole process of the activities.

3. Participants were motivated to keep on learning English.

4. Participants admitted that the activities were so beneficial to their job, they also wished this type of activity to be conducted routinely.

5. Participant and related agency showed their gratitude to the organizer.

Based on the explanation above, these things listed below were highlighted:

1. English training to Sunday School Children needs to be carried on as conducted at Tabur Kasih Malalayang, for it was able to improve their ability in using English and increase their interest to English.

2. The cooperation between English Education Department, Agency of National Education Manado City, and Board of Tabur Kasih, needs to be increase to support tourism factor especially in Manado.

\section{Conclusion}

\section{Conclusion}

$>$ To learn English as foreign language especially for Indonesia needs appropriate technique of learning. by its position as a foreign language, English was considered as a challenge to teacher and students.

$>$ Community service activity in form of English training to Sunday Scholl Children of Manado Tabur Kasih Congregation had been successfully conducted.

The implementation of this training had reached the goal for all participants were able to master and apply English orally. 
Journal of Educational Method and Technology Vol. 1 No. 2, September 2018

P-ISSN 2622-8459 E-ISSN 2622-8467

http://ejournal.unima.ac.id/index.php/jemtec

Suggestion

By looking at the success obtained and participants' energy, it was suggested that community service activity in form of training needs to be carried on either at the same or different place with the same topic to young generation in different location.

\section{References}

Gareis, E. (2000). 'Two Thumbs Up! A Students Video Production' dalam English Teaching FORUM vol 38 no. 1 Januari-Maret 2000.

Gareis, E. (2000). 'Two Thumbs Up! A Students Video Production' in English Teaching FORUM vol 38 no. 1 January - March 2000.

Goodwin, A., Hamrick, J., \& Steawart, T.C. (1993). 'Instructional Delivery Via Electronic Mail' dalam TESOL Journal, 3 24-27

Goodwin, A., Hamrick, J., \& Steawart, T.C. (1993). 'Instructional Delivery Via Electronic Mail' in TESOL Journal, 3 24-27

Hardie, E.T.L., \& Neou, V. (Eds). (1993). Internet: Mailing Lists (SRI Internet Information Series). Englewwod Cliffs, NJ: Regents Prentice Hall.

Hasman, Melvia A. (2000). 'The Role Of English In The 21st Century' dalam English Teaching FORUM. Januari 2000.

Hasman, Melvia A. (2000). 'The Role Of English In The 21st Century' in English Teaching FORUM. January 2000.

Helena I.R. Agustien (2004). Pedoman Penyusunan Rencana Pengajaran Bahasa Inggris Untuk Kurikulam 2004. Makalah di TOT Puskur.

Helena I.R. Agustien (2004). Guide on Planning of English Teaching for 2004. Magazine at TOT Puskur.

Higgins, Chris (1993). 'Computer Assisted Language Learning: Currents Programs and Projects' dalam ERIC Didgest. April 1993.

Higgins, Chris (1993). 'Computer Assisted Language Learning: Currents Programs and Projects' in ERIC Didgest. April 1993.

Hubbard, Peter et al. (1993). A training course for TEFL. Oxford: Oxford University Press.

Kang, Shumin (1999). 'Learning Styles: Implication For ESL/ESL Instruction' dalam

English Teaching FORUM vol. 37 no. 4 Oktober-Desember 1999.

Kang, Shumin (1999). 'Learning Styles: Implication For ESL/ESL Instruction' in English Teaching FORUM vol. 37 no. 4 October-December 1999.

Krause, J. (1989). Telecommunications In Foreign Language Education: A Resource List dalam Eric Digest. Washington, DC: ERIC Clearinghouse on Language and Linguistics.

Krause, J. (1989). Telecommunications In Foreign Language Education: A Resource List in Eric Digest. Washington, DC: ERIC Clearinghouse on Language and Linguistics.

Krol, E. (1992). The Whole Internet. Sebastopol, CA: O'Reilly \& Associates. 
Journal of Educational Method and Technology Vol. 1 No. 2, September 2018

P-ISSN 2622-8459 E-ISSN 2622-8467

http://ejournal.unima.ac.id/index.php/jemtec

Kurshan, B.L., Harrington, M.A., \& Milbury, P.G. (1994). An Educator's Guide To Electronic Networking: Creating Visual Communities. Syracuse, NY: ERIC Clearinghouse on Information and Technology.

LeLoup, Jean W., \& Robert Ponterio. (2000). 'Enhancing Authentic Language Learning Experinces Through Internet Technology dalam ERIC Digest EDO-FL-00-02.

Lonergan, J. (1994). Video in Language Teaching. New York: Cambridge University Press.

Marcos, Kathleen. (1994). Internet Ffor Language Teachers. ERIC Clearinghouse on Language and Linguistics. 